\section{Water Use of Hydrangea macrophylla and Gardenia jasminoides in Response to a Gradually Drying Substrate}

\author{
Lucas O'Meara, Matthew R. Chappell, and Marc W. van Iersel ${ }^{\mathbf{1}}$ \\ Department of Horticulture, The University of Georgia, 1111 Miller Plant \\ Sciences Building, Athens, GA 30602
} Additional index words. conductance, load cell, plant-available water, substrate water content,
transpiration

\begin{abstract}
As a result of the lack of quantitative data regarding specific water requirements of ornamental species, precision irrigation can be a difficult task for nursery growers. One challenge for growers is that it is not clear how much of the water in soilless substrates is actually available for plant uptake. Substrate moisture release curves (MRC) have been used to predict the amount of plant-available water in soilless substrates, yet there is little information about whether there are differences among species in their ability to extract water from substrates. The objectives of this study were to determine 1) the hydraulic properties of a composted pine bark substrate; and 2) how water uptake in Hydrangea macrophylla and Gardenia jasminoides was affected by decreasing substrate volumetric water content (VWC). As the substrate VWC decreased from 0.38 to $0.17 \mathrm{~m}^{3} \cdot \mathrm{m}^{-3}$, substrate matric potential decreased from -4.0 to $-69 \mathrm{kPa}$, whereas hydraulic conductivity decreased from 0.115 to $0.000069 \mathrm{~cm} \cdot \mathrm{d}^{-1}$. To measure plant water uptake in a drying substrate, growth chambers were used to provide stable environmental conditions that included continuous lighting to prevent diurnal fluctuations in water use. Water use by $H$. macrophylla 'Fasan' started to decrease at a higher VWC $\left(0.28 \mathrm{~m}^{3} \cdot \mathrm{m}^{-3}\right)$ than G. jasminoides 'Radicans' $\left(0.20 \mathrm{~m}^{3} \cdot \mathrm{m}^{-3}\right)$. Plant water uptake stopped at a VWC of $0.16 \mathrm{~m}^{3} \cdot \mathrm{m}^{-3}$ in $\mathrm{H}$. macrophylla and $0.12 \mathrm{~m}^{3} \cdot \mathrm{m}^{-3}$ in G. jasminoides. The results show that $H$. macrophylla is less adept at extracting water from a drying substrate than $G$. jasminoides. Traditionally, plant-available water in soilless substrates has been studied using substrate MRCs. Our data suggest that substrate hydraulic conductivity may be an important factor controlling water availability to the plants. In addition, there are important differences among species that cannot be detected by only looking at substrate hydraulic properties.
\end{abstract}

Precision irrigation of ornamental plants can be a difficult task for nursery growers as a result of the lack of quantitative information regarding the specific water needs of different plant species. To prevent drought stress and ultimately crop losses and/or reductions in growth rate resulting from dehydration, many growers apply excessive amounts of irrigation (Kim et al., 2011; Mathers et al., 2005). This strategy can lead to leaching and runoff of fertilizer and pesticides from the substrate. Majsztrik et al. (2011) and Million et al. (2007) have shown that by reducing leaching of fertilizer from container-grown ornamentals, nurseries can reduce production costs and increase profits. Previous research has also shown that efficient irrigation systems

Received for publication 26 Nov. 2013. Accepted for publication $12 \mathrm{Feb} .2014$.

This research was funded by the Center for Applied Nursery Research in Dearing, GA, and USDANIFA-SCRI (award no. 2009-51181-05768).

We thank Sue Dove for technical assistance and Bob Teskey, John Ruter, and three anonymous reviewers for their suggestions on an earlier version of the manuscript.

${ }^{1}$ To whom reprint requests should be addressed; e-mailmvanier@uga.edu. and proper scheduling can save significant amounts of irrigation water without adversely affecting crop yield or quality in ornamental production (Bacci et al., 2008; Beeson, 2012; Fereres et al., 2003). By using soil moisture sensor-based, automated irrigation systems, precision irrigation can be effectively implemented in ornamental plant production (Chappell et al., 2013). One critical piece of information for the implementation of soil moisture sensor-based irrigation is the substrate water content at which plants need to be irrigated. Because not all water in substrates is available to plants, it is important to know how much of the water in the substrate can be used by plants. It is generally proposed that plants can no longer take up water from a soilless substrate at a VWC less than $0.20 \mathrm{~m}^{3} \cdot \mathrm{m}^{-3}$ (Drzal et al., 1999; Milks et al., 1989b). However, previous studies have shown that various species can grow below this proposed threshold for water availability (e.g., Burnett and van Iersel, 2008; van Iersel et al., 2010). Thus, the effect of VWC on the ability of different species to take up water from soilless substrates needs further research.

When plants are exposed to decreasing water availability, they respond by progressively closing their stomates to reduce transpiration and prevent dehydration (Sperry et al., 2002; Tezara et al., 1999), although the severity of the drought response is speciesspecific (Niu et al., 2006). Some of the more drought-tolerant plants can undergo osmotic adjustment in the root and leaf tissues that enable the plant to preserve the water potential gradient necessary to facilitate water uptake under drought conditions (Hsiao and $\mathrm{Xu}, 2000)$. As the water content within the plant decreases, cells will begin to lose turgor, resulting in decreased leaf expansion and root elongation. When cell turgor approaches zero, leaves wilt (Taiz and Zeiger, 2002). When the substrate becomes too dry for a plant to extract water from the substrate, the plant will no longer be able to maintain transpiration, ultimately causing the death of the plant. The soil/ substrate water potential at which plants can no longer take up enough water to recover, even if transpiration is negligible, has been termed the permanent wilting point (PWP) (Tolk, 2003). A common assumption for field crops is that there is no plant-available water at a soil water potential less than $-1.5 \mathrm{MPa}$ based on research conducted by Furr and Reeve (1945) on the PWP of sunflowers. As a consequence, a pressure plate apparatus is commonly used to determine the VWC at which the matric potential is $-1.5 \mathrm{MPa}$ to determine the PWP in different soils/substrates (Tolk, 2003). However, the actual water potential threshold for the PWP of different plants is dependent on the relationship among plant species, soil type, and weather (Taiz and Zeiger, 2002; Tolk, 2003). In addition, the ability of plants to take up water from soils or soilless substrates not only depends on the matric potential, but also on the hydraulic conductivity of that soil or substrate. The hydraulic conductivity of soils and substrates decreases as the soil or substrate dries out (Campbell and Campbell, 1982). As a consequence, low hydraulic conductivity may slow water movement in drying substrates and thus limit plant water uptake (van Iersel et al., 2013).

When comparing soilless substrates and soil, VWC at a matric potential of $-1.5 \mathrm{MPa}$ differs significantly between a mineral soil $\left(0.162 \mathrm{~m}^{3} \cdot \mathrm{m}^{-3}\right.$; Cecil clay loam) and a barkbased substrate $\left[0.215 \mathrm{~m}^{3} \cdot \mathrm{m}^{-3} ; 3\right.$ bark: 1 sand: 1 peat (v:v:v)] (Milks et al., 1989b). Drzal et al. (1999) suggested that water present in a soilless substrate at a water potential below $-1.5 \mathrm{MPa}$ is bound within ultramicropores and is unavailable to plants based on the pressure/tension required to extract such water in a laboratory setting. However, when applied to actual plant material grown in soilless substrates, moisture release theory may not accurately reflect the ability of plants to take up water from soilless substrates. Lobet et al. (2014) recently emphasized the importance of combining soil and plant hydraulic properties for predicting plant water uptake and the same likely holds true for soilless substrates.

In studies conducted on the water requirements of bedding plants in peat-based substrates, a VWC of $0.15 \mathrm{~m}^{3} \cdot \mathrm{m}^{-3}$ was not low enough to cause a severe inhibition of growth in vinca (Catharanthus roseus), petunia 
(Petunia $\times$ hybrida) (Nemali and van Iersel, 2005), or chrysanthemum (Chrysanthemum $\times$ morifolium) (Olson et al., 2002). van Iersel and Dove (2005) also concluded that there was no effect of VWC on whole-plant photosynthesis of abelia (Abelia $\times$ grandiflora) or hydrangea (Hydrangea macrophylla) at a VWC greater than $0.15 \mathrm{~m}^{3} \cdot \mathrm{m}^{-3}$ in a bark-based substrate and that wilting did not occur until VWC reached $0.06 \mathrm{~m}^{3} \cdot \mathrm{m}^{-3}$ for abelia and $0.08 \mathrm{~m}^{3} \cdot \mathrm{m}^{-3}$ for hydrangea. Thus, plants can grow at VWC levels well below the commonly used $0.20 \mathrm{~m}^{3} \cdot \mathrm{m}^{-3}$ threshold for plant-available water. Plant water use at different VWCs may be more indicative of the actual availability of substrate water to plants than measuring substrate hydraulic properties. Therefore, we conducted this study to quantify the hydraulic properties of a bark-based substrate and to determine the relationship between substrate VWC and plant water uptake and conductance in Hydrangea macrophylla and Gardenia jasminoides. Our objectives were to determine how much of the water present in a pine barkbased substrate is actually plant-available and to test whether this is species-dependent, as suggested by van Iersel and Dove (2005).

\section{Materials and Methods}

\section{Expt. 1: Substrate hydraulic properties}

Unused substrate made from composted pine bark was obtained from a commercial nursery (McCorkle Nurseries, Dearing, GA). The hydraulic properties of this substrate were determined using a modular instrument (Hyprop, UMS, München, Germany) with two precision mini-tensiometers at different heights placed on a precision balance. The tensiometers measure the matric potential gradient within the substrate, expressed both in pressure units $(\mathrm{kPa})$ and as $\mathrm{pF}[-\log ($ matric potential)]. The balance measures evaporation from the substrate surface. Weight measurements are also used to determine the changes in VWC throughout the measurement period.

The 250-mL soil sampling ring was handfilled from the top with substrate, which was subsequently saturated. Data collection started after the tensiometers were inserted into the substrate and the substrate with tensiometers was placed on the balance. Data collection was performed using software specifically designed for this purpose (TensioView, UMS). Data collection took $12 \mathrm{~d}$, after which data were analyzed using data evaluation software (Hyprop, UMS). This software determines a MRC for the substrate and can also determine hydraulic conductivity of the substrate, but only when the substrate is relatively dry (VWC less than $0.38 \mathrm{~m}^{3} \cdot \mathrm{m}^{-3}$ ). For more details on this technique, see Peters and Durner (2008a, 2008b). The Hyprop software was also used to fit a bimodal van Genuchten curve to the MRC curve (Durner, 1994). The bimodal van Genuchten curve is the weighted sum of two van Genuchten curves and commonly used for soils or substrates with a bimodal pore size distribution, i.e., relatively many large and small pores but few pores of intermediate size:

$$
S_{e}(h)=\sum_{i=1}^{2} w_{i}\left[\frac{1}{1+\left(\alpha_{i}|h|\right)^{n_{i}}}\right]^{1-\left(\frac{1}{n_{i}}\right)}
$$

A Mualem curve was fitted to the conductivity data (Mualem, 1976):

$$
K_{r}\left(S_{e}(h)\right)=S_{e}^{\tau}\left[\frac{\int_{0}^{S_{e}} h^{-1} d S_{e}(h)}{\int_{0}^{1} h^{-1} d S_{e}(h)}\right]^{2},
$$

where

$$
S_{e}=\frac{V W C-V W C_{r}}{V W C_{s}-V W C_{r}}
$$

In these equations, $\mathrm{S}_{\mathrm{e}}=$ effective saturation, $\mathrm{h}=$ matric potential (in $\mathrm{hPa}$ ), $\mathrm{w}_{\mathrm{i}}=$ relative weight of the two van Genuchten equations, $\alpha_{i}$ and $n_{i}=$ shape factors for each curve, $\mathrm{K}_{\mathrm{r}}=$ relative hydraulic conductivity, $\tau=$ tortuosity parameter for the Mualem curve, $\mathrm{VWC}_{\mathrm{r}}=$ residual $\mathrm{VWC}$, and $\mathrm{VWC}_{\mathrm{s}}=$ saturated VWC. The Mualem curve describes the shape of the conductivity function based on the shape of the MRC. To determine the actual hydraulic conductivity $\left(K_{h}\right)$ from the saturated hydraulic conductivity $\left(\mathrm{K}_{\mathrm{s}}\right)$ and the Mualem model:

$$
K_{h}=K_{s} \times K_{r}(h)
$$

For more details on this analysis and the theory behind it, see Pertassek et al. (2011).

\section{Expt. 2: Plant water uptake from a drying substrate}

Plant material. For this experiment, mature container specimens of Hydrangea macrophylla 'Fasan' and Gardenia jasminoides 'Radicans' were used to determine stomatal responses to declining substrate water content. The plants were potted 1 year before the onset of this study in \#2 containers $(6.0 \mathrm{~L}$; $22.5 \mathrm{~cm}$ high $\times 22 \mathrm{~cm}$ deep) (Nursery Supply, Chambersburg, PA) filled with a typical commercial nursery substrate containing composted pine bark, $1.97 \mathrm{~kg} \cdot \mathrm{m}^{-3}$ lime, $0.74 \mathrm{~kg} \cdot \mathrm{m}^{-3}$ Micromax (Everris, Dublin, OH), $0.74 \mathrm{~kg} \cdot \mathrm{m}^{-3}$ gypsum, $1 \mathrm{~kg} \cdot \mathrm{m}^{-3}$ Talstar (Bifenthrin $0.2 \%$ ) (FMC Professional Solutions, Philadelphia, PA), and $1.98 \mathrm{~kg} \cdot \mathrm{m}^{-3}$ Osmocote Pro $18-6-12$ $(18.0 \mathrm{~N}-2.6 \mathrm{P}-10.0 \mathrm{~K})$ (Everris).

Experimental setup and data collection. The study took place in two growth chambers (E15 and PGR15; Conviron, Winnipeg, Canada) set to maintain temperature at $25{ }^{\circ} \mathrm{C}$. Overhead banks of fluorescent and incandescent lights were adjusted to a height that provided an above-canopy light level of $560 \mu \mathrm{mol} \cdot \mathrm{m}^{-2} \cdot \mathrm{s}^{-1}$. There were minor variations in light intensity at the canopy level, primarily as a result of differences in plant height between species. Lighting was applied constantly to prevent diurnal fluctuations in water use from obscuring the subtle changes in stomatal conductance $\left(g_{\mathrm{S}}\right)$ expected to occur at low substrate water contents. Light levels were measured at the start of each run using a handheld light bar (SQ-326; Apogee Instruments; Logan, UT) positioned over the tallest plant in the chamber. The height of the lamp canopy was adjusted to provide similar light levels in both growth chambers. The growth chambers were not equipped with humidity control, and changes in outdoor weather conditions resulted in changes in relative humidity inside of the growth chambers.

Data were collected and stored by a data logger with two multiplexers (CR10 and AM25T; Campbell Scientific, Logan, UT) to facilitate the various sensors used. Temperature and relative humidity were measured every 5 min (HTO-45D; Rotronic, Hauppauge, NY) within each growth chamber and the data logger calculated vapor pressure deficit (VPD) values from these data.

At the study's onset, containers were submerged in a large tub of water filled to the substrate surface level and soaked for $1 \mathrm{~h}$ to ensure saturation of the substrate. Containers were then allowed to drain for $15 \mathrm{~min}$ before being placed in growth chambers. Plants were randomly assigned to a load cell and growth chamber location with three load cells within each growth chamber. Plant weight was measured every $10 \mathrm{~s}$ using individually calibrated load cells (LSP-10; Transducer Techniques, Temecula, CA) mounted on steel base plates with an acrylic platform attached to the top of the load cell. The substrate surface was covered with aluminum foil to limit evaporation to assure that weight changes accurately reflected transpiration. Substrate VWC was also measured every $10 \mathrm{~s}$ using capacitance soil moisture sensors (10HS; Decagon Devices, Pullman, WA) calibrated specifically for this substrate. Average plant weight and VWC measurements were stored every 5 min until water loss had stopped. The remaining water in the substrate was considered to be the plantunavailable water. At that time, the study was repeated with a new set of plants. An overview of the setup is shown in Figure 1.

The difference in hourly average weight was used to calculate whole-plant transpiration rates $\left(\mathrm{T}_{\mathrm{wp}}\right)$. Using $\mathrm{T}_{\mathrm{wp}}$, whole-plant conductance rates $\left(g_{w p}\right)$ were calculated using the formula:

$$
\mathrm{g}_{\mathrm{wp}}=\mathrm{T}_{\mathrm{wp}} /(\mathrm{VPD} / 101)
$$

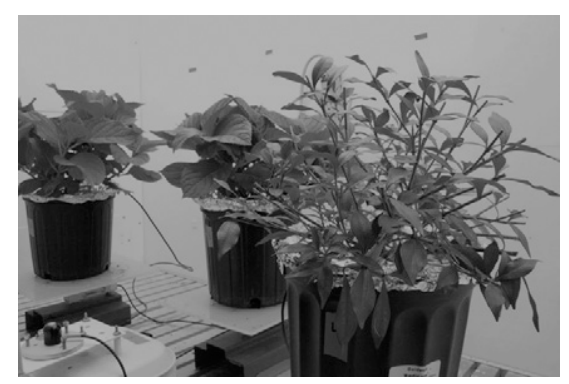

Fig. 1. Overview of three plants on load cells inside of a growth chamber. The substrate surface was covered with aluminum foil to minimize evaporation from the substrate surface. A soil moisture sensor was inserted into each container. Load cells were used to monitor water loss (transpiration), whereas the soil moisture sensors measured substrate volumetric water content. A quantum sensor on top of a radiation shield containing a temperature and humidity sensor can be seen in the bottom left of the picture. All sensors were connected to a data logger for automated data collection. 
where VPD is the hourly average vapor pressure deficit $(\mathrm{kPa})$ and 101 is the atmospheric pressure $(\mathrm{kPa})$. Aboveground biomass of dead plants was removed and the substrate was weighed, dried at $80{ }^{\circ} \mathrm{C}$, and then re-weighed. The decrease in plant + pot weight from the start to the conclusion of the run was used to determine total amount of water lost during the study. The shoots were then cutoff and the difference in the weight of the substrate at harvest and after oven-drying was used to determine the amount of water still in the substrate. The sum of these equaled the amount of water that was present in the substrate at the beginning of the study (container capacity), which averaged $2003 \pm 136 \mathrm{~mL}$.

The accuracy of the soil moisture sensor readings was confirmed by the gravimetrically determined VWC values at the start and finish of the study. Soil moisture sensor readings averaged $0.396 \pm 0.027 \mathrm{~m}^{3} \cdot \mathrm{m}^{-3}$ at the start of the study and $0.109 \pm 0.013 \mathrm{~m}^{3} \cdot \mathrm{m}^{-3}$ at the conclusion. Gravimetrically determined water contents averaged $0.384 \pm 0.032 \mathrm{~m}^{3} \cdot \mathrm{m}^{-3}$ at the start of the study and $0.072 \pm 0.017 \mathrm{~m}^{3} \cdot \mathrm{m}^{-3}$ at the end. The larger discrepancy between sensor readings and gravimetrically determined VWC at the end of the study was likely the result of evaporation from the substrate surface, resulting in a non-uniform distribution of water in the substrate.

Statistical analysis. The experimental design was a randomized complete block with six replications for each species; three in each run. To determine the VWC threshold values when whole-plant transpiration and conductance was first limited by VWC and when it stopped, transpiration and conductance were plotted vs. VWC. A spline regression was then performed on the data collected from each plant (Proc NLIN, Statistical Analysis Software Version 9.2; SAS, Cary, NC):

$$
\begin{aligned}
& \mathrm{Y}=\mathrm{b}_{0}+\mathrm{b}_{1} \cdot \mathrm{VWC}-\mathrm{b}_{2} \cdot \mathrm{VWCdelta}, \\
& \text { where VWCdelta }=\max [(\text { VWC-knot }), 0]
\end{aligned}
$$

where $\mathrm{y}=$ transpiration or conductance; $\mathrm{b}_{0}$, $\mathrm{b}_{1}$, and $\mathrm{b}_{2}$ are regression coefficients; and knot is the VWC at which the two regression lines intersect (i.e., the VWC below which transpiration or conductance starts to decrease). Goodness of fit was tested by calculating an $R^{2}$ value as model sum of squares/ corrected total sum of squares. Using the associated equation for the regression lines, we were able to determine the VWC at which transpiration and plant conductance ceased for each plant. Transpiration and plant conductance were determined to have ceased when they reached a rate of $1.5 \mathrm{~mL} \cdot \mathrm{h}^{-1}$ and $75 \mathrm{~mL} \cdot \mathrm{h}^{-1}$, respectively, and subsequent weight loss was attributed to evaporation from the substrate. These thresholds were chosen, because measured transpiration was close to $1.5 \mathrm{~mL} \cdot \mathrm{h}^{-1}$ after the plants were desiccated and appeared dead. Threshold VWC values for reduction and cessation of both transpiration and conductance in each plant were analyzed by standard analysis of variance to test for differences between the two species (Proc ANOVA; SAS).

\section{Results and Discussion}

Substrate hydraulic properties. Total pore space of the substrate was $\approx 0.75 \mathrm{~m}^{3} \cdot \mathrm{m}^{-3}$ and the substrate matric potential decreased to $\approx-700 \mathrm{kPa}$ at a substrate VWC of $0.17 \mathrm{~m}^{3} \cdot \mathrm{m}^{-3}$ $(\mathrm{pF}=-2.84)$ (Fig. 2). Hydraulic conductivity could be determined within a VWC range of 0.17 to $0.38 \mathrm{~m}^{3} \cdot \mathrm{m}^{-3}$ (pF of 1.60 to 2.84 ). As the substrate dried from a VWC of 0.38 to $0.17 \mathrm{~m}^{3} \cdot \mathrm{m}^{-3}$, the hydraulic conductivity decreased from 0.115 to $0.000069 \mathrm{~cm} \cdot \mathrm{d}^{-1}$, a $1665 \times$ decrease. Such a drastic decrease in substrate hydraulic conductivity will limit the rate of water movement through the substrate to the roots (Campbell and Campbell, 1982) and this may limit water availability to the plants.

Environmental conditions. Temperature in the growth chambers was maintained between 25.2 and $26.5{ }^{\circ} \mathrm{C}$ (Fig. 3). Relative humidity ranged from $4.3 \%$ to $65.1 \%$, resulting in VPD values between 1.15 and $3.13 \mathrm{kPa}$ (Fig. 3). Although there were small differences in environmental conditions between the two growth chambers, conditions fluctuated in a similar fashion.

Transpiration and conductance. Wholeplant transpiration rates (Fig. 4) gradually decreased over time as water was lost through evapotranspiration. Spline regression curves of transpiration vs. VWC [Eq. (6)] generally indicated a strong relationship between these two factors (average $R^{2}$ for hydrangea and gardenia of 0.95 and 0.85 , respectively). The transpiration rate slowed at a higher VWC in hydrangea than in gardenia. Whole-plant transpiration rates of hydrangea began to gradually decrease at a VWC of $0.277 \pm 0.019 \mathrm{~m}^{3} \cdot \mathrm{m}^{-3}$ (mean $\pm \mathrm{SD}$ ), likely as a result of stomatal regulation in response to decreasing water availability (Fig. 5; Table 1). At a VWC of $0.158 \pm 0.013 \mathrm{~m}^{3} \mathrm{~m}^{-3}$, the transpiration rate neared zero and plateaued at a rate of 1.5 to $2.0 \mathrm{~mL} \cdot \mathrm{h}^{-1}$ for the duration of the study. This was deemed to be the point where water bound to the substrate was no longer plantavailable and subsequent weight loss was attributed to water evaporating from the substrate surface and drain holes in the bottom of the container. Whole-plant transpiration rates of gardenia began to gradually decrease at a VWC of $0.202 \pm 0.028 \mathrm{~m}^{3} \cdot \mathrm{m}^{-3}$ and ceased at a VWC of $0.119 \pm 0.028 \mathrm{~m}^{3} \cdot \mathrm{m}^{-3}$ (Fig. 5; Table 1). Whole-plant conductance behaved in a similar manner with a reduction occurring in
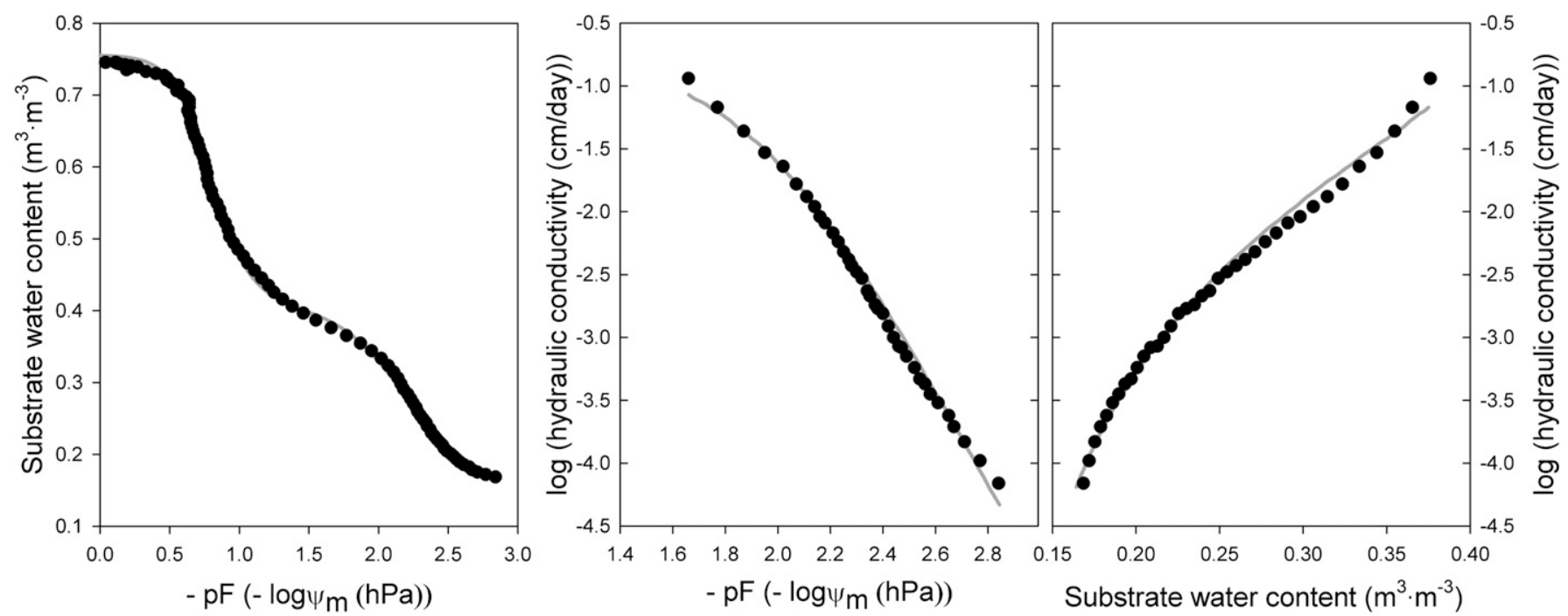

Fig. 2. Substrate moisture characteristics of the pine bark substrate used in this study. (Left) Substrate moisture release curve [water content vs. pF (the logarithm of the substrate matric potential in $\mathrm{kPa}$ )]. (Middle and Right) Substrate hydraulic conductivity as a function of $\mathrm{pF}$ and substrate water content. Note that the hydraulic conductivity is shown on a $\log$ scale. Curves were fitted using Eqs. [1 to 4], where $\alpha_{1}=0.1809 \mathrm{~cm}^{-1}, \mathrm{n}_{1}=3.468, \mathrm{w}_{1}=0.547, \mathrm{VWC}_{\mathrm{r}}=0.114 \mathrm{~m}^{3} \cdot \mathrm{m}^{-3}$, $\mathrm{VWC}_{\mathrm{s}}=0.756 \mathrm{~m}^{3} \cdot \mathrm{m}^{-3}, \alpha_{2}=0.0089 \mathrm{~cm}^{-1}, \mathrm{n}_{2}=1.991$, and $\mathrm{w}_{2}=0.453, \tau=-0.179$, and $\mathrm{K}_{\mathrm{s}}=121.7 \mathrm{~cm} \cdot \mathrm{d}^{-1}$. Root mean square error for VWC and $\log (\mathrm{hydraulic}$ conductivity) is $0.0093 \mathrm{~m}^{3} \cdot \mathrm{m}^{-3}$ and 0.0744 , respectively. VWC $=$ volumetric water content. 


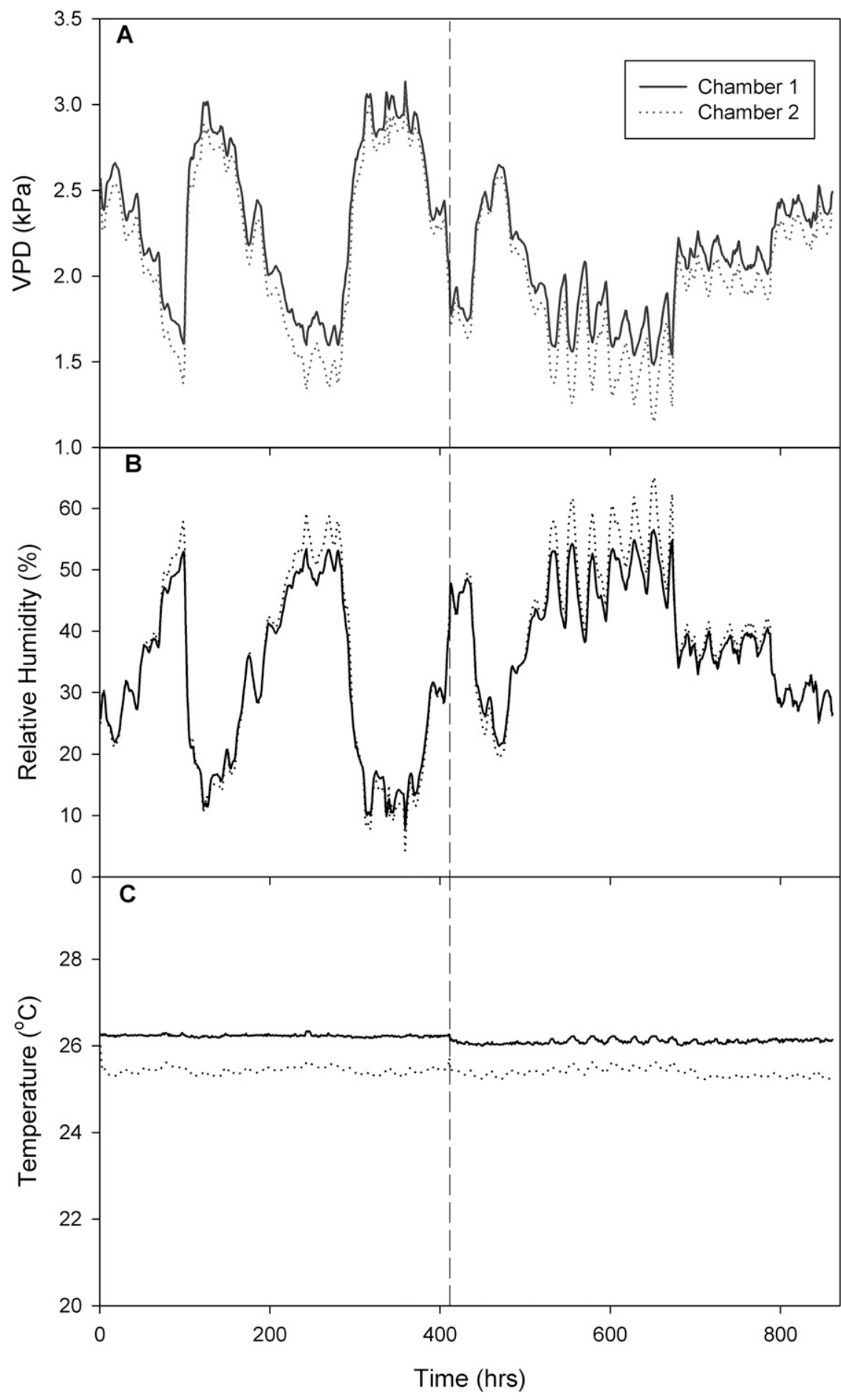

Fig. 3. Average vapor pressure deficit, relative humidity, and temperature over the 5-week study. The vertical dashed line indicates when the second run was started.

hydrangea at a VWC of $0.287 \pm 0.024 \mathrm{~m}^{3} \cdot \mathrm{m}^{-3}$ and ceasing at a VWC of $0.157 \pm 0.006 \mathrm{~m}^{3} \cdot \mathrm{m}^{-3}$. In gardenia, the reduction in conductance occurred at a VWC of $0.205 \pm 0.046 \mathrm{~m}^{3} \cdot \mathrm{m}^{-3}$ and ceased at a VWC of $0.120 \pm 0.009 \mathrm{~m}^{3} \cdot \mathrm{m}^{-3}$ (Fig. 5; Table 1).

Our finding that reduction and cessation of whole-plant conductance occurred at different VWCs for hydrangea and gardenia supports earlier findings by Nemali and van Iersel (2008) and Niu et al. (2006), illustrating species differences in water uptake and
Breakage of the water column within xylem vessels can result in decreased plant conductance and a reduction in the tension required to maintain water uptake at low VWCs.

The persistence of transpiration and $g_{\mathrm{S}}$ at VWCs well below levels that have been regarded as plant-unavailable suggests that MRCs for soilless substrates are not accurate indicators of water availability to plants. Research conducted on MRCs of soilless substrates has asserted that plants are unable to extract water at water potentials below -1.5 MPa (Milks et al., 1989a, 1989b) translating to a VWC of $0.215 \mathrm{~m}^{3} \cdot \mathrm{m}^{-3}$ in a bark-based substrate (Milks et al., 1989b). Much of the research on MRCs for soilless substrates is only performed to a pressure/tension of $30 \mathrm{kPa}$ (Altland et al., 2010; Fonteno and Nelson, 1990; Milks et al., 1989a, 1989b; Wallach et al., 1992), at which Milks et al. (1989b) found a pine bark-based substrate to have a VWC of $0.227 \mathrm{~m}^{3} \cdot \mathrm{m}^{-3}$. Given that a specialized pressure plate system is required to apply a pressure/tension of $1500 \mathrm{kPa}$ and that an additional pressure/tension of $1470 \mathrm{kPa}$ only extracts an additional $0.012 \mathrm{~m}^{3} \cdot \mathrm{m}^{-3}$ of water from a bark-based substrate, development of MRCs within a range of 0 to $30 \mathrm{kPa}$ has been deemed practically sufficient. Although MRC-related studies conducted over the last $20+$ years have been used to compare different types of soilless substrates, those studies have not determined how easily that water was available. de Boodt and Verdonck (1972) defined water held between a matric potential of -1 and $-5 \mathrm{kPa}$ as easily available water, between -5 and $-10 \mathrm{kPa}$ as the water buffering capacity, and below $-10 \mathrm{kPa}$ as less readily available water. Although these classifications have been widely used, they seem somewhat arbitrary and unrelated to whether plants are capable of taking up that water from the substrate. Our finding that transpiration was maintained until a VWC of $0.16 \mathrm{~m}^{3} \cdot \mathrm{m}^{-3}$ and $0.12 \mathrm{~m}^{3} \cdot \mathrm{m}^{-3}$ in hydrangea and gardenia, respectively, is contradictory to the proposed VWC thresholds for water availability and is corroborated by the observations of Nemali and van Iersel (2005), Olson et al. (2002), and van Iersel and Dove (2005). Furthermore, the drastic decrease in substrate hydraulic conductivity as the substrate dries out raises the possibility that low hydraulic conductivity may contribute to limiting water availability to plants (van Iersel et al., 2013). The importance of the substrate hydraulic conductivity in assuring continued water flow through the substrate to the roots has received little attention so far.

Of the total volume of substrate, we found that $0.24 \mathrm{~m}^{3} \cdot \mathrm{m}^{-3}$ consisted of plant-available water for hydrangea and $0.27 \mathrm{~m}^{3} \cdot \mathrm{m}^{-3}$ was plant-available water for gardenia (Table 1), which is less than the amounts proposed by Drzal et al. (1999; $\left.0.315 \mathrm{~m}^{3} \mathrm{~m}^{-3}\right)$ and Milks et al. $\left(1989 \mathrm{~b} ; 0.30\right.$ to $\left.0.45 \mathrm{~m}^{3} \cdot \mathrm{m}^{-3}\right)$. This is likely because substrate saturation in MRC studies is generally imposed by slowly adding water to the base of the pressure vessel over the course of 24 to $48 \mathrm{~h}$, expelling any 


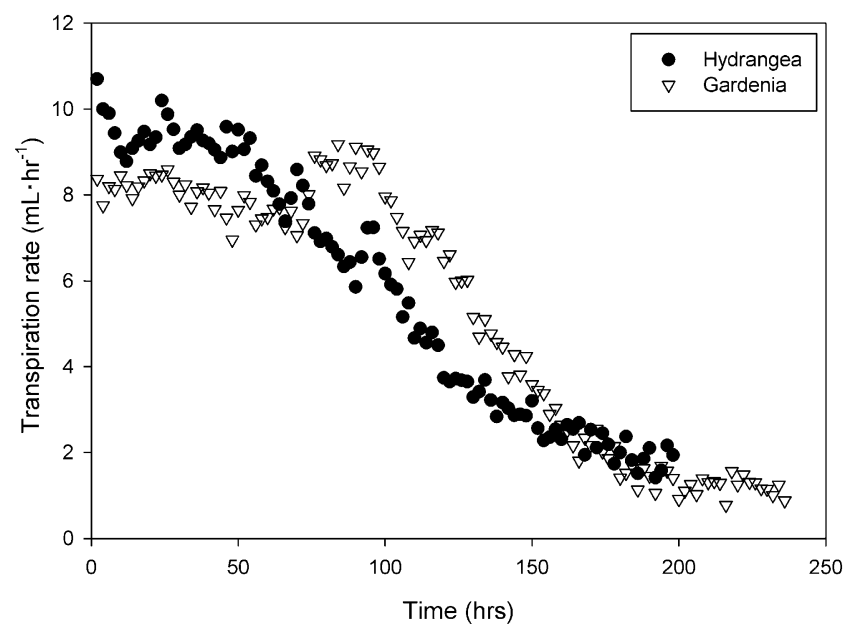

Fig. 4. Whole-plant transpiration rates of representative Hydrangea macrophylla 'Fasan' and Gardenia jasminoides 'Radicans' plants over time. Plants were not watered during this period.

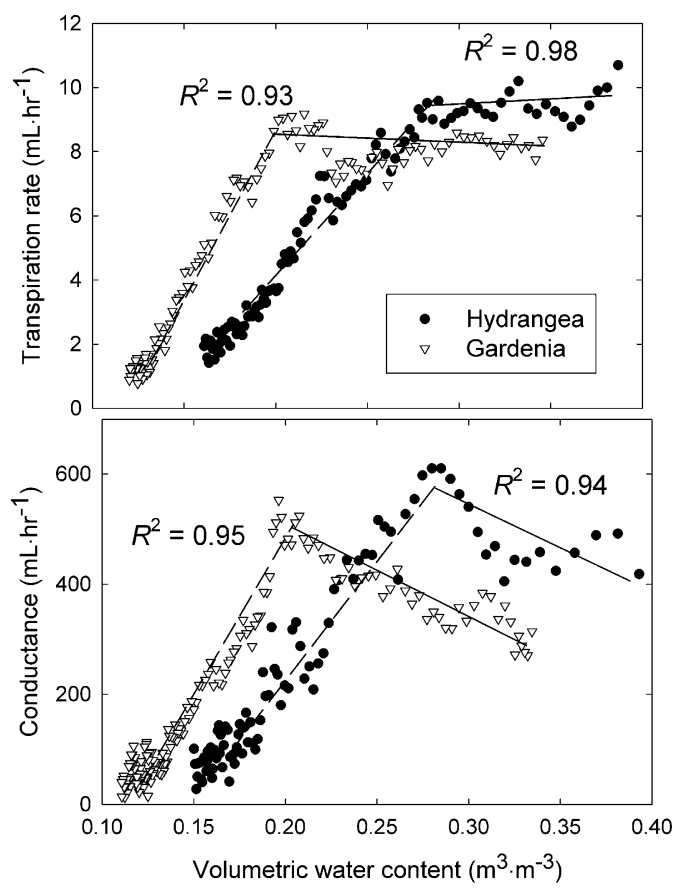

Fig. 5. Whole-plant transpiration and conductance rates of representative Hydrangea macrophylla 'Fasan' and Gardenia jasminoides 'Radicans' plants in response to decreasing substrate water content. Lines indicate the results of piecewise regression used to determine the water content at which transpiration and conductance start to decrease and become negligible.

Table 1. Volumetric water contents $(m e a n \pm S D)$ at which a reduction and cessation in whole-plant conductance occurred and plant-available water content (expressed as a percent of total amount of water at container capacity and as percent of substrate volume) for Hydrangea macrophylla 'Fasan' and Gardenia jasminoides 'Radicans'.

\begin{tabular}{lcccc}
\hline Species & $\begin{array}{c}\text { Reduction in } \\
\text { conductance }(\mathrm{v} / \mathrm{v})\end{array}$ & $\begin{array}{c}\text { Cessation of } \\
\text { conductance }(\mathrm{v} / \mathrm{v})\end{array}$ & $\begin{array}{c}\text { Plant-available water } \\
(\% \text { of total water })\end{array}$ & $\begin{array}{c}\text { Plant-available water } \\
(\% \text { of substrate volume })\end{array}$ \\
\hline $\begin{array}{c}\text { Hydrangea } \\
\text { macrophylla }\end{array}$ & $0.287 \pm 0.024 \mathrm{a}$ & $0.157 \pm 0.006 \mathrm{a}$ & 60 & 24 \\
$\begin{array}{c}\text { Gardenia } \\
\text { jasminoides }\end{array}$ & $0.205 \pm 0.046 \mathrm{~b}$ & $0.120 \pm 0.009 \mathrm{~b}$ & 69 & 27 \\
\hline
\end{tabular}

${ }^{2}$ Means followed by the same letter are not significantly different $(P<0.05)$. Note that plant-available water was not analyzed statistically, because no data for individual experimental units were available.

air pockets within the substrate. Because our main objective was to determine the VWC at which transpiration and conductance were inhibited, submersing the containers in water for $1 \mathrm{~h}$ was deemed to sufficiently represent
Our results show that both species were able to maintain transpiration, and presumably water uptake, down to a VWC that is much lower than the suggested threshold for plant-available water in soilless substrates. Additional research quantifying the response of whole-plant conductance to decreasing substrate water contents for a broader selection of ornamental species, with the added parameters of observing initial wilting points and the analogous VWC as well as substrate matric potential, could be beneficial to understanding species-dependent limitations of water uptake in soilless substrates. Likewise, comparisons of different substrate will be informative, especially if differences in MRCs and substrate hydraulic conductivity are taken into account.

\section{Conclusions}

The hydraulic conductivity of a composted pine bark substrate dropped drastically as VWC decreased from 0.38 to $0.17 \mathrm{~m}^{3} \cdot \mathrm{m}^{-3}$, which decreases the mass flow of water to the root surface. This can impact the ability of plants to extract water from the substrate, but this effect may be species-specific. Transpiration of Hydrangea macrophylla 'Fasan' and Gardenia jasminoides 'Radicans' in gradually drying substrate was inhibited when VWC dropped below 0.29 and $0.21 \mathrm{~m}^{3} \cdot \mathrm{m}^{-3}$, respectively. Hydrangea was unable to extract water from the pine bark-based substrate at a VWC less than $0.16 \mathrm{~m}^{3} \cdot \mathrm{m}^{-3}$, whereas gardenia was unable to extract water at a VWC less than $0.12 \mathrm{~m}^{3} \cdot \mathrm{m}^{-3}$. These VWC limits for plantavailable water are substantially lower than those previously proposed based on MRCs. Our results also indicate that the plant species needs to be taken into account when determining the amount of plant-available water in soilless substrates. Of the $2003 \pm 136 \mathrm{~mL}$ (mean \pm SD) of water held at container capacity, $60 \%$ was available to hydrangea and $69 \%$ was available to gardenia. This information, and subsequent studies like it, can be used to increase the precision of deficit irrigation in ornamental production by detailing optimal and minimum VWC thresholds to be maintained for different species.

\section{Literature Cited}

Altland, J.E., J.S. Owen, and W. C. Fonteno. 2010 Developing moisture characteristic curves and their descriptive functions at low tensions for soilless substrates. J. Amer. Soc. Hort. Sci. 135: 563-567.

Bacci, L., P. Battista, and B. Rapi. 2008. An integrated method for irrigation scheduling of potted plants. Sci. Hort. 116:89-97.

Beeson, R.C., Jr. 2012. Development of a simple reference evapotranspiration model for irrigation of woody ornamentals. HortScience 47: 264-268.

Bramley, H., N.C. Turner, D.W. Turner, and S.D Tylerman. 2009. Roles of morphology, anatomy, and aquaporins in determining contrasting hydraulic behavior of roots. Plant Physiol. 150:348-364.

Burnett, S.E. and M.W. van Iersel. 2008. Morphology and irrigation efficiency of Gaura lindheimeri 
grown with capacitance sensor-controlled irrigation. HortScience 43:1555-1560.

Campbell, G.S. and M.D. Campbell. 1982. Irrigation scheduling using soil moisture measurements: Theory and practice. Adv. Irr. 1:25-42.

Chappell, M., S.K. Dove, M.W. van Iersel, P.A. Thomas, and J. Ruter. 2013. Implementation of wireless sensor networks for irrigation control in three container nurseries. Hort Technology 23:747-753.

de Boodt, M. and O. Verdonck. 1972. The physical properties of the substrates used in horticulture. Acta Hort. 26:37-44.

Drzal, M.S., W.C. Fonteno, and D.K. Cassel. 1999. Pore fraction analysis: A new tool for substrate testing. Acta Hort. 481:43-54.

Durner, W. 1994. Hydraulic conductivity estimation for soils with heterogeneous pore structure. Water Resour. Res. 30:211-223.

Fereres, E., D.A. Goldhamer, and L.R. Parsons. 2003. Irrigation water management of horticultural crops. HortScience 38:1036-1042.

Fonteno, W.C. and P.V. Nelson. 1990. Physical properties of and plant responses to rockwoolamended media. J. Amer. Soc. Hort. Sci. 115: 375-381.

Furr, J.R. and J.O. Reeve. 1945. Range of soilmoisture percentages through which plants undergo permanent wilting in some soils from semi-arid irrigated areas. J. Agr. Res. 71:149170.

Hsiao, T.C. and L.-K. Xu. 2000. Sensitivity of growth of roots versus leaves to water stress: Biophysical analysis and relation to water transport. J. Expt. Bot. 51:1595-1616.

Kim, J., M.W. van Iersel, and S. Burnett. 2011. Estimating daily water use of two petunia cultivars based on plant and environmental factors. HortScience 46:1287-1293.

Lobet, G., V. Couvreur, F. Meunier, M. Javaux, and X. Draye. 2014. Plant water uptake in drying soils. Plant Physiol. (in press).
Majsztrik, J., A.G. Ristvey, and J.D. Lea-Cox. 2011. Water and nutrient management in the production of container-grown ornamentals. In: Janick, J. (ed.). Hort. Reviews. Wiley, Hoboken, NJ. 38:253-297.

Mathers, H.M., T.H. Yeager, and L.T. Case. 2005. Improving irrigation water use in container nurseries. Hort Technology 15:8-12.

McElrone, A.J., W.T. Pockman, J.M. Vilata, and R.B. Jackson. 2004. Variation in xylem structure and function in stems and roots of trees to $20 \mathrm{~m}$ depth. New Phytol. 163:507-517.

Milks, R.R., W.C. Fonteno, and R.A. Larson. 1989a. Hydrology of horticultural substrates: I. Mathematical models for moisture characteristics of horticultural container media. J. Amer. Soc. Hort. Sci. 114:48-52.

Milks, R.R., W.C. Fonteno, and R.A. Larson. 1989b. Hydrology of horticultural substrates: II. Predicting physical properties of media in containers. J. Amer. Soc. Hort. Sci. 114:53-56.

Million, J., T. Yeager, and J. Albano. 2007. Consequences of excessive overhead irrigation on runoff during container production of sweet viburnum. J. Environ. Hort. 25:117-125.

Mualem, Y. 1976. A new model for predicting the hydraulic conductivity of unsaturated porous media. Water Resour. Res. 12:513-521.

Nemali, K.S. and M.W. van Iersel. 2005. Water requirements and drought tolerance of bedding plants. HortScience 40:1115 (abstr.).

Nemali, K.S. and M.W. van Iersel. 2008. Physiological responses to different substrate water contents: Screening for high water-use efficiency in bedding plants. J. Amer. Soc. Hort. Sci. 133:333-340.

Niu, G., D.S. Rodriguez, and Y.-T. Wang. 2006 Impact of drought and temperature on growth and leaf gas exchange of six bedding plant species under greenhouse conditions. HortScience 41:1408-1411.

Olson, D.L., R.D. Oetting, and M.W. van Iersel. 2002. Effect of soilless potting media and water management on development of fungus gnats (Diptera: Sciaridae) and plant growth. HortScience 37:919-923.

Pertassek, T., A. Peters, and W. Durner. 2011. HYPROP data evaluation software user's manual, V.1.0. UMS GmbH, Munich, Germany.

Peters, A. and W. Durner. 2008a. Simplified evaporation method for determining soil hydraulic properties. J. Hydrol. (Amst.) 356:147-162.

Peters, A. and W. Durner. 2008b. A simple model for describing hydraulic conductivity in unsaturated porous media accounting for film and capillary flow. Water Resour. Res. 44:W11417.

Sperry, J.S., U.G. Hacke, R. Oren, and J.P. Comstock. 2002. Water deficits and hydraulic limitations to leaf water supply. Plant Cell Environ. 25:251263.

Taiz, L. and E. Zeiger. 2002. Plant physiology. 3rd Ed. Sinauer Associates Inc., Sunderland, MA.

Tezara, W., V.J. Mitchell, S.D. Driscoll, and D.W. Lawlor. 1999. Water stress inhibits plant photosynthesis by decreasing coupling factor and ATP. Nature 401:914-917.

Tolk, J.A. 2003. Soils, permanent wilting points. Encyclopedia of water science. Marcel Dekker, New York, NY.

van Iersel, M.W., M.R. Chappell, and J. Lea-Cox. 2013. Sensors for improved efficiency of irrigation in greenhouse and nursery production. HortTechnology 23:735-746.

van Iersel, M.W. and S. Dove. 2005. Whole-plant photosynthesis of containerized hydrangeas and abelias as affected by substrate moisture content. HortScience 40:1111 (abstr.).

van Iersel, M.W., S. Dove, J.-G. Kang, and S.E. Burnett. 2010. Growth and water use of petunia as affected by substrate water content and daily light integral. HortScience 45:277-282.

Wallach, R., F.F. Da Silva, and Y. Chen. 1992. Unsaturated hydraulic characteristics of composted agricultural wastes, tuff, and their mixtures. Soil Sci. 153:434-441 (abstr.). 